\title{
Conserving Conflict? Transfrontier Conservation, Development Discourses and Local Conflict Between South Africa and Lesotho
}

\author{
Julia M. Wittmayer • Bram Büscher
}

Published online: 9 December 2010

(C) The Author(s) 2010. This article is published with open access at Springerlink.com

\begin{abstract}
This paper describes and analyses how discourses of conservation and development as well as migrant labour practices can be understood as transnational dynamics that both cement and complicate transnational relations. It also looks into how these dynamics articulate with, shape and are being shaped by 'the local'. Focusing on the north-eastern boundary of Lesotho in the area of the 'Maloti-Drakensberg transfrontier conservation and development project', we show how conflictual situations put the ethnographic spotlight on the ways in which 'local people' in Lesotho deal with dual forces of localisation and transnationalisation. We argue that they accommodate, even appropriate, these dual pressures by adopting an increasingly flexible stance in terms of identity, alliances, livelihood options and discourses.
\end{abstract}

Keywords Transfrontier Conservation and Development Areas · Local identities, livelihoods and alliances .

Ecotourism · South Africa $\cdot$ Lesotho

\section{Introduction}

When his dad worked in the South African mines during the 1970s, Morebane Ramonotsi, like many other young

\footnotetext{
J. M. Wittmayer $(\triangle)$

Faculty of Social Sciences, Erasmus University Rotterdam, Rotterdam, the Netherlands

e-mail: wittmayer@fsw.eur.nl

B. Büscher

Institute of Social Studies, Erasmus University Rotterdam,

Rotterdam, the Netherlands

B. Büscher

Department of Geography, Environmental Management \& Energy

Studies, University of Johannesburg,

Johannesburg, South Africa
}

Basotho ${ }^{1}$ boys, gained early experience in herding the family cattle. The steady family income allowed him to finish secondary education after which he started to work for the Lesotho Highlands Water Project (LHWP), initiated by the South African and Lesotho governments during the mid 1980s. Following his ambitions he went to South Africa to study Electrical Engineering. When he returned, however, the construction phase of the LHWP had ended and with it many job opportunities had ceased to exist. Together with his brother, Morebane decided to utilise a family hut to start a bed and breakfast for development workers and tourists. Now 35, Morebane's irregular income from the $B \& B$, which he shares with his family, is supplemented byamong other activities-working on the family fields, as an election officer, as an assistant in archaeological work, as the co-founder of the Moteng Ponytrekking Association, as the co-founder of the local farming association, and as secretary of the District Steering Committee of the 'MalotiDrakensberg Transfrontier Project.' The diversity and range of his activities has been criticised by a community facilitator as sign of greediness, while he regards them as necessary and smart livelihood strategies. He recently married his fiancée, a shop assistant in the Chineseowned clothing shop in the nearby town, and wants to build her a brick house, preferred by young Basotho women over traditional huts. ${ }^{2}$

It is immediately clear from this brief description of the current life situation of a villager in the north-eastern part of Lesotho that 'local' is a rather contrived concept here. Contrary to many popular conservation and development

\footnotetext{
${ }^{1}$ Basotho (plural, Mosotho, singular) are people of Sotho origin. The majority of Lesotho's population is Basotho, with very small Asian and European minorities. The term 'Basotho' will be used here to refer to both the people of Sotho origin who also live in other parts of Southern Africa and the population of Lesotho.

${ }^{2}$ This description is taken from the first author's field notes.
} 
policy images of 'the local' and of 'communities,' Morebane's livelihood has 'transnationalism,' 'multiple identity' and 'mixed livelihoods' written all over it. The research presented is based on our assumption that 'the local' in Lesotho cannot be understood without reference to transnational relations and the broader political economy of the Southern African region. 'The local' in Lesotho is an intricate and complex amalgamation of trans-boundary political interests, economic dependencies, cultural and social ties, ecological circumstances, historical events and traditions. In continuing to assume the perseverance of livelihood strategies centred on narrow concepts of 'community' and 'the local,' international conservation and development discourses and interventions - particularly those adhering to an ideal of communitybased natural resource management (CBNRM) - further complicate this picture and consequently often contribute to a widening gap between discourses and realities of what 'the local' entails.

This article describes how international conservation and development discourses both cement and complicate transnational relations and how they in turn articulate with, shape and are being shaped by 'the local. ${ }^{3}$ What we refer to as 'the local' exists through, is shaped by and pervades the transnational/global and vice versa (Davids and van Driel 2005; Hughes 2006). In order to achieve a better understanding of these processes we analyse two recent dynamics in north-eastern Lesotho and the role of conflict therein. The first dynamic is the transnationalising presence of the large World Bank-sponsored 'Maloti-Drakensberg transfrontier conservation and development project' (MDTP), which aims to conserve the biodiversity of the Maloti-Drakensberg mountain ecosystem that runs across the eastern border of Lesotho with South Africa while simultaneously improving the livelihoods of local communities in the area through tourism. The second dynamic is of the opposite order: the localising pressures stimulated by massive retrenchments of Lesotho mineworkers from South African mines. On many occasions these forces clashed. By focussing on the level of discourse rather than the contradiction of these two dynamics on the local level, the MDTP intervention planners decreased the likelihood of attaining their objectives (see Büscher 2009).

Two local conflicts - one caused by a MDTP-proposed protected area and the other by a proposed golf estate in South Africa-illustrate how transnational influences incite, provoke, shape and modify local dynamics and vice versa. We argue that these dual interacting pressures of transnationalisation and localisation are accommodated and even appropriated by the local populations, who adopt an increasingly flexible stance in terms of identity, alliances

\footnotetext{
${ }_{3}^{3}$ See West (2006) and Dressler (2009) for comparable analyses in Papua New Guinea and the Philippines respectively.
}

and discourses in order to increase their livelihood options and at the same time reconfirm the multiple, interconnected identities and dynamics that make up 'the local'.

We first present background information on transfrontier conservation by focusing on the complex role and positioning of 'the local' within (theoretical) transnationalising discourses of conservation and development. We then show how this complexity can be found in north-eastern Lesotho within the framework of the Maloti-Drakensberg intervention. In the following section we discuss the two local conflicts and the way in which transnational discourses are used in the organisation of local opposition. Finally, we present our conclusions.

\section{Transnational Conservation and Local Development}

Conservation in Southern Africa has a long history (Anderson and Grove 1987; Neumann 1998; Adams and Hulme 2001; Beinart and McGregor 2003). Yet, in order to understand how conservation has 'conserved conflict' in the region through its problematic engagement with rural people, it is important to provide some brief historical notes on conservation and its recent culmination in the transfrontier movement.

Overviews in the literature normally commence by describing conservation during colonialism and apartheid. Over a decade ago, Ghimire and Pimbert (1997: 14) wrote that "parks and reserves have become a major source of rural tension in most developing countries." More recently, Fabricius (2004: 9) argued that "it is now widely accepted that the particular style of official natural resource management that emerged in Southern Africa during the colonial and apartheid periods generated a range of social conflicts that now endanger the future of natural resources." A multitude of reasons is brought forth for these conflicts, including (inter alia): forced removal, enforcement of reduced or no access to land and resources, and general extension of state control through conservation. Taken together, these approaches became known as 'fortress conservation' (Brockington 2002; Brockington et al. 2008).

In Southern Africa 'fortress conservation' made way-at least at the level of discourse - for a more socially inclusive approach during the 1980s and 1990s. The emerging model became known as community-based conservation or, more commonly in Southern Africa, community-based natural resource management (CBNRM). The main principles underlying this paradigm are: community consultation, acknowledgement of human suffering due to conservation, acknowledgement of the value of communal traditions and ways of natural resource management, and enhanced (negotiating) rights for rural people in terms of access to and sharing of resources, for instance in protected areas. While CBNRM is 
the dominant paradigm today, it is not hegemonic in practice; the extensive literature on 'communities and conservation' continually emphasises different issues in discourse and practice (Brosius et al. 2005; Dressler et al. 2010).

Igoe and Fortwangler (2007: 66) suggest that the current academic debate revolves around four main issues: "(1) the ways communities are historically constituted in the context of conservation interventions; (2) the role of external actors/ agencies (e.g., state, NGOs, private enterprise) in this process, and other types of communities not often acknowledged in the literature; (3) the central role of networks of governance (as opposed to government) in conceptualizing and implementing conservation; and (4) the neoliberalisation of conservation." We focus on the first issue for the remainder of this section to introduce transfrontier conservation and to provide a solid background for the other three issues, which will be touched upon in later sections.

The problematic historical constitution of local communities in the context of conservation also pervades the implementation of one of the latest trends in conservation: Transfrontier Conservation and Development Areas (TFCAs) (Büscher 2010b). They cross international state borders and subsume multiple land use forms. As 'ambitious projects in nature,' they aim at biodiversity conservation, the crossborder alignment of land tenure systems, the economic development of local people by promoting conservation as a land use option, and the promotion of peace and cooperation between nations. ${ }^{4}$ At the time of writing, 12 TFCAs are actively being developed in Southern Africa and an additional two are in a conceptual phase. ${ }^{5}$

Local populations are generally regarded as having interests and land uses conflicting with these aims. In seeking to involve them in biodiversity conservation, TFCAs promise them, besides training, income possibilities mostly through ecotourism (Dressler and Büscher 2008). Ecotourism, however, is often a double-edged sword. While it can provide income possibilities, it is also often criticized for generating unrealistic expectations, unevenly distributing benefits, and exacerbating social differences (Orlove and Brush 1996; Marcus 2001; West and Brockington 2006). Moreover, tourism often utilizes images of local communities as living 'authentically' with unchanging traditions and culture and 'in balance with nature' (Draper et al. 2004). Obviously—as, for instance, our introductory description of Morebane Ramonotsi's livelihood situation clearly showed - this is a myth. The point is that 'authentic culture' sells, and as such is increasingly commoditised, while often disguising power struggles about access to and use of land in the process (Hughes 2002; Spierenburg and Wels 2006). So far, TFCAs

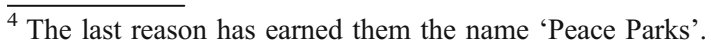

${ }^{5}$ See Peace Parks Foundation http://www.peaceparks.org/ Content_1060000000_Maps.htm (accessed October 22, 2010).
}

have not been able to address these problems effectively (Duffy 2006; Hughes 2006; Büscher and Dressler 2007; Dressler and Büscher 2008).

On the surface then, 'the local' is portrayed as a partner in the community-based transfrontier conservation paradigm, but more often than not local communities are still seen as a threat to biodiversity who seemingly need to be 'dragged' off the(ir) land (Wolmer 2003; Spierenburg and Wels 2006; Dressler and Büscher 2008). Although usually well-intentioned, the aim of benefitting the local population through conservation always runs the risks of the adverse effects outlined above. In the end, it often seems that the advantages promised to local communities participating in TFCAs serve to legitimise interventions and mask the conflicts inherent in what are basically struggles over access to and control over land and natural resources (Duffy 2006; Ribot and Peluso 2003). Yet, these struggles do not always necessarily lead to local conflict; they could also lead to opportunities for (at least parts of) local communities. In the next section we discuss both the problematic and the potential of transnational conservation and development within the framework of the MalotiDrakensberg Transfrontier Project.

\section{Transnational Discourses of Conservation and Development Between South Africa and Lesotho}

One of the TFCAs in Southern Africa currently progressing most rapidly is the 'Maloti-Drakensberg Transfrontier Conservation and Development Project' (MDTP) between South Africa and Lesotho. The project area encompasses $8,113 \mathrm{~km}^{2}$, of which $64 \%$ is in Lesotho, with an altitude range from 1,300 to $3,200 \mathrm{~m}$ above sea level. It includes three districts in Lesotho (Botha-Bothe, Mokhotlong, Quacha's Nek) and parts of three provinces in South Africa (KwaZulu-Natal, Free State, Eastern Cape).

With a population of almost two million people, the area has a variety of land uses ${ }^{6}$ and different tenure systems. The MDTP was envisioned more than two decades ago by conservationists in South Africa and Lesotho, but it was only in 2001 that both governments signed a Memorandum of Understanding establishing the actual TFCA and paving the way for the MDTP intervention. It commenced in 2003 and was funded by the Global Environment Facility through the World Bank for a period of five years. Both Lesotho and South Africa had their own implementation structures consisting of a strategic Project Coordination Committee and a Project Coordination Unit that in practice

\footnotetext{
${ }^{6}$ These are national parks, nature reserves, commercial farms, subsistence farming, grazing land, range management areas and settlements.
} 
did most of the work. The two Project Coordination Committees together formed the Bilateral Steering Committee, which was the highest decision-making body in the project and consisted of staff members of relevant government organisations and parastatal stakeholders.

Our research on the MDTP was carried out from 2003 to 2008 (second author) and January-April 2007 (first author). Whereas the second author focused on the overall MDTP intervention in both countries using multi-level analysis and participatory observation, interview and documentary methodologies, the first author concentrated on the interaction on the local level in and around the north-eastern part of Lesotho combining participatory observation with interviews. The remainder of this and the next section focuses especially on this border area of the Botha-Bothe district. The South African border area will be addressed from the perspective of the impact transnational relations and dynamics have on the people in the north-east of Lesotho.

Comparable to other TFCAs, the MDTP aims to conserve the biological and cultural diversity of the region and to further economic development of the local population through ecotourism. These objectives are legitimised by a discourse postulating the necessity of urgent action to save biodiversity. ${ }^{7}$ The roles and functions of 'the local' within this discourse are highly ambiguous. On the one hand, 'the local' is constituted as an intruder in nature whose interests conflict with those of a conserved environment-in fact portrayed as unsustainably exploiting biological resources and vandalising cultural resources. ${ }^{8}$ On the other hand, 'the local' is depicted as the ultimate 'manager' of the natural resources; the 'natural caretaker' of the biological diversity for the benefit of all (MDTP 2006, see also Büscher 2009). Yet, despite this 'innate' capability, the MDTP feels the need to introduce behavioural training, informational public gatherings and ecotourism initiatives to motivate people to collaborate towards the conservation goal. This paradoxical construction of 'the local' as either in harmony with nature or environmentally destructive is a topic often addressed in the literature (e.g., Holt 2005). Since both perspectives are based on the arbitrary presupposition that 'locals' indeed solely depend on local livelihood strategies (Hughes 2005), they continue to plague conservation and development interventions.

Turning from discourse to practice, yet another picture of 'the local' within the MDTP emerges. An examination of the MDTP's organisational structure reveals that much of the actual implementation of the project is carried out on an extralocal (national, international) level, prioritising planning, research and consultancies over on-the-ground 'dirty-boots' work (Büscher 2009). In Lesotho, the MDTP on the local

\footnotetext{
${ }^{7}$ See www.maloti.org (accessed March 3, 2010).

${ }^{8}$ See www.maloti.org (accessed March 3, 2010).
}

level was mostly engaged in capacity building projects, 'sensitisation' exercises and pilot tourism initiatives. Initial local reactions towards the MDTP focusing on possible economic and commercial possibilities were positive (Büscher 2010a). Yet, overall, it seemed that little to none of the intended effects of the intervention materialized for most villagers. Interviews in the village of Nyakoaneng, ${ }^{9}$ part of an MDTP pilot project area, for example, revealed that not even half of the interviewees knew the MDTP and its work in 2007. Those who did know about the MDTP were part of an MDTP institution, a participant in an MDTPinitiated training, a member of a local institution, or a relative of someone in one of those groups. A small group of interviewees had heard about the MDTP once in a public gathering but nothing more after that. A picture of 'the local' emerges as individuals interested in the economic possibilities of the intervention but little preoccupied with its objectives. Yet, this is not to say that the intervention had no effects at all on the local level. ${ }^{10}$ For these to become more readily apparent, however, they had to be triggered by specific dynamics, for instance, the probability of conflict.

\section{Conflict and Community Around the North-Eastern Lesotho Border}

The lives and identities of the Basotho living in northeastern Lesotho have for long been shaped by and have shaped transnational processes. The MDTP, in this respect, is only a very recent and minor element. In the 1830 s, during the time of the Difaqane - the 'times of trouble'many African peoples were displaced by Zulu aggression and expansion, as well as by the 'Great Trek,' the northwards March of the Boers ${ }^{11}$ to escape British rule. The Basotho, under Chief Moshoeshoe, were forced to retreat to the mountains and eventually to accept a settlement whereby they lost most of their fertile land to the Boers (Thompson 2006). As a result, people of Sotho origin live on both sides of the South Africa-Lesotho border and still dispute its legitimacy. They refer to the lost land, a large part of the South African Free State, as 'Conquered Territory' (Coplan 2001). By challenging the legitimacy of the border they are able to voice their very local economic hardships, which are exacerbated by the loss of the land. Interestingly, the MDTP, as a 'transfrontier' project, has renewed the attention to the border issue, and even further reinforced its contingent historical nature. In fact, as we shall see, the transnationalising dynamics unleashed by the

\footnotetext{
${ }^{9}$ Botha-Bothe district, north-eastern Lesotho.

${ }^{10}$ See Wittmayer (2007), for some of the (unintended) effects of the intervention, such as the enhancement of local state presence and the simplification of land administration.

11 'Boers' are descendents of Dutch settlers in South Africa.
} 
MDTP have both complicated transnational relations between Basotho in South Africa and Lesotho and strengthened them.

Economically, the livelihoods of the population in Lesotho have always been tied to South Africa. In the late nineteenth century, South African mines were the key market for excess crops of successful farmers. Lesotho's economy, however, was drastically impacted when, among other changes, the South African government introduced protectionist measures. ${ }^{12}$ By the 1930s Lesotho had developed into a "labour reserve" (Murray 1981: 1), providing migrant labour for the mines in Gauteng and the farms in the Free State. This process peaked in the 1970s and 1980s, when crucial livelihood support was provided through migrant labour activities and remittances. Subsequent falling gold prices and a restructuring within the mining industry have led to massive retrenchments. Tens of thousands of men returned to their fields in Lesotho $^{13}$ and tried to reintegrate with their families and communities. In the village of Nyakoaneng, where up to $90 \%$ of the men used to work in the mines, their return had a massive socio-economic impact as families could no longer rely on at least one steady income. Some of the men used their redundancy payments to become entrepreneurs in their villages - often unsuccessfully. More successful have been some of the younger men for whom a career at the mines was not as certain as it had once been for many Basotho men. Morebane Ramanotsi with his innovative idea of setting up a bed and breakfast is a good, although exceptional, example. The general picture, though, is of a certain re-focussing on more 'traditional' local and localised activities: farming and cattle herding. But successful farming on Lesotho's mountain soils is highly contingent on external cash inputs, which had been provided by remittances from migrant labourers, for buying fertilizer or paying for timely ploughing (Murray 1981; Ferguson 1994; Boehm 2003a; Turner 2005b). In this sense, these macro-economic changes have directly affected rural life all over Lesotho. Moreover, the return of the miners and their efforts to re-establish livelihoods in the local context has sparked what could be called a localisation dynamic, whereby 'local' is again being redefined within the range of multiple identities of the Basotho.

Thus, livelihoods and identities in Lesotho have to be understood in relation to their historical formation and current

\footnotetext{
12 Other changes were cheaper imports from overseas and within Lesotho the introduction of the hut tax, armed conflict and the need for weapons, livestock epidemics and a series of droughts and locust attacks (See Murray 1981; Ferguson 1994, 2006; Boehm 2003a; Turner 2005a).

${ }^{13}$ According to Chris Hector, Regional Manager for Lesotho and the Eastern Free State at the Employment Bureau of Africa (TEBA) a decline from up to 130,000 miners in the 1970 s and 1980 s to around 50,000 at present (Boehm 2003b: 4).
}

embeddings as a consequence of interactions with South Africa as well as the rest of the world. For example, there are increasing influences on the society by Asian immigrant entrepreneurs and Asian textile companies offering employment to young women, and of course the global aid industry, which despite some decline in interest, is still a formidable presence in the country (especially the capital). ${ }^{14}$ The Basotho themselves construct their social and economic spaces transnationally as they live, work, study, visit friends or shop across the border - whether they live in the 'Conquered Territory' or the north-eastern part of Lesotho.

The following two case studies - the disputed plans of a new national park in Lesotho and a golf course in South Africa, both directly on the international border-illustrate some of the pressures of localisation and transnationalisation on the lives, livelihoods and identities of the Basotho in north-eastern Lesotho, and the role of conflict therein.

\section{Case 1: The Proposed Liqobong National Park in Lesotho and Its Link with Golden Gate National Park in South Africa}

Establishing transfrontier parks within larger transfrontier conservation areas serves to strengthen the stature of the overall TFCA, as well as the institutional bonding between the countries involved. It is important to note here the difference between a transfrontier park and a transfrontier area. Whereas the former usually focuses on one single land-use (often strict conservation) the latter subsumes multiple types of land-use as mentioned earlier. From this perspective, the MDTP has been keen to establish a second border-spanning national park connecting Golden Gate National Park in South Africa with a counterpart in northeastern Lesotho. ${ }^{15}$ Yet, the planning of the creation of the counterpart in Lesotho has already provoked local protest.

From 2006, the MDTP has been investigating the establishment of a national park close to the border in Lesotho, in an area known as 'Liqobong'. According to the MDTP Lesotho Protected Area planner, ${ }^{16}$ the national park would protect the important 'sponge area' of the Caledon River - the area that catches and concentrates the rainfall at the river's origin - and create a surrounding buffer area where human movement is allowed. The further rationale for the protected area he presented revolved around three issues considered strategically important for Lesotho. First, it would help the country to come closer to fulfilling its

\footnotetext{
${ }^{14}$ See Ferguson (1994) for an interesting but dated overview of the presence of the aid industry in Lesotho.

${ }^{15}$ Within the MDTP area, Sehlabathebe National Park in Lesotho has been linked to uKhahlamba Drakensberg Park World Heritage Site in South Africa since 2007.

${ }^{16}$ Personal Interview, January 16, 2007, in Maseru, Lesotho.
} 
obligations under the Convention of Biological Diversity to put $10 \%$ of its land aside for conservation. Second, it would boost local economic development by creating employment opportunities, and third, the new protected area would enhance Lesotho's international reputation as a tourist destination. This top-down approach shows clearly that CBNRM is not hegemonic in practice but also that considerations about communities were secondary. The maps used by the MDTP reflected neither local land uses nor the fact that the area is historically regarded as sacred-people use it for prayer and to make sacrifices for rain. ${ }^{17}$ Consequently, parts of the population in the area were not convinced by the MDTP arguments and intensely resisted the plans. In October 2006, a group of around 30 local cattle herders articulated their disapproval in a letter to the Ombudsman of the Lesotho government, stating that on the land in question, they were grazing cattle, farming and visiting graves of their ancestors. They even expressed their fears that the whole plan was a scam to sell the land to South Africa.

The consultation process resulted in a meeting in February 2007 of the project advocates (local MDTP staff and state representatives), the protesters and the local population to discuss the objections against the park. ${ }^{18}$

During this meeting the project advocates argued that the 'whole community' had been involved in participation processes from the start, including activities such as public gatherings, an area tour, the establishment of a Community Conservation Forum and a tour to visit communities living next to two already existing national parks. The protesters, however, had not used those participatory or other common traditional mediation methods (e.g., the chiefly structure) to voice their concerns. During the meeting some were even denying that these activities had taken place at all. Instead, for voicing their concerns, they relied on a modern democratic instrument, namely the institution of the Ombudsman, although during the meeting it became clear that the protesters had no knowledge about the working of the modern democratic processes they had appealed to. As stated by one of the protestors: "We were expecting the Ombudsman and want to talk to him, not to these institutions. We do not want development and prefer it the way it is. We'd rather stay hungry. Poverty is better than development." Another said: "I am 70 years and I am wasting my time because the Ombudsman is not here." It

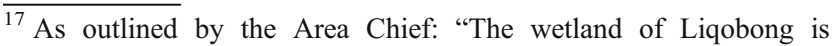
important for us, because people pray there for rain. After 1962 [the year his Christian mother as wife of the Principal Chief banned it], this has become less, but still I know of people taking a sheep there, slaughter it and pray for rain." Personal Interview, March 15, 2007, in Makhunoane, Lesotho.

${ }^{18}$ The meeting was held on February 1st, 2007 just outside the village of Mafikalisiu and was attended by both authors.
}

was clear that the MDTP, departing from a certain assumption of the 'local', inherent in the CBNRM discourse had chosen for ways of consultation that were not able to address the concerns about land access and use nor the historically constituted fear of the local population about 'losing' their land to South Africa.

Instead, MDTP staff explained the protests as well as the appeal to the Ombudsman as the result of externalnational and transnational-influences that were inciting and taking advantage of local fears for political gain, holding out the possibility of local support for the protected area. This convenient explanation was first presented at an earlier MDTP meeting in January 2007 at the Lesotho Northern Parks headquarters in Botha Bothe, when the MDTP Botha Bothe Regional Officer, outlining the state of plans for the proposed park, stated that when they started discussing the idea with the local communities it "went wrong": the issue became politicised and the communities even thought that their (Lesotho) land was going to be sold to South Africa. Besides that, there was resistance from cattle owners, who according to the MDTP Regional Officer also "think we are going to take their land." Another MDTP Officer added that with land issues, many people automatically think of the "the lost land in the Free State," as he referred to the Conquered Territory. He stated that political parties, in the heated national election campaign of 2007, were accusing each other of wanting to sell land to South Africa. He added that "the interests in the area are bigger than the area can accommodate." As the number of people using the Liqobong area is bigger than the number of people living there it is hard to address all their interests. In short, the MDTP firstly argued that local interests and fears were being manipulated during the then ongoing national election campaigns by politicians of the opposition party, and secondly, that local cattle herders were being mobilized to oppose the park by a rich cattle owner from South Africa cooperating with them in the border region where the national park was to be created. The struggle about access to and use of a certain area of land which protesters voiced was neither taken at face value nor seriously addressed by the MDTP.

During the meeting, the project advocates attempted to convince the cattle herders to change their stance through what they considered rational reasoning. The lawyer of the Community Council for example, referring to the Land Act 1979, said: "There will not be an enforcement of the park onto you, but negotiations. There will be compensations should you be adversely affected by the creation of a park." Their reasoning was influenced by an evolutionary model of development thinking whereby the 'developed' project advocates help the 'naïve' locals to see the (economic, social, etc.) opportunities that would arise from a protected area- and they were partially successful. One said for example: "You only 
reject the park because you do not know how beneficial it is. In this you think like children." Advocates employed rationalistic development discourse and the prospect of a possible economic advantage to legitimise the intervention and to mask the underlying struggles over access to and control over natural resources that are at times exacerbated by returning miners trying to find their local bearings again.

Despite the rather hostile atmosphere during the meeting evidenced by threats and physically separated groups - it also became clear that the conflict was not limited to the MDTP and the local community but was taking place within the "local community" as well. On the one hand, spurred on by cross-boundary cattle networks, there were protestors in the local community that opposed the park vigorously, stating not only that poverty is better than development but also that if the park materializes they "will fight." On the other hand, it appeared that a great majority of 'the community' with interests in Liqobong - which seemed to include even villages $30 \mathrm{~km}$ from the actual proposed site, including Nyakoaneng where we did the bulk of our research - had in fact never heard of the plans for a protected area in Liqobong. Asked for their opinion, the villagers were near unanimous in their approval of a protected area, including Morebane Ramonotsi. The Chief of Nyakoaneng, for example, said that she likes it, "because people can then see what good grazing land looks like." ${ }^{19}$ She even supported access restrictions, trusting that people will still get some advantages out of the park. Another villager, ${ }^{20}$ who is also a member of the MDTP District Steering Committee, mentioned he "would like Liqobong to go on because it again will bring more tourists." In particular, he stated that it will then be a network of protected areas, from Golden Gate to Liqobong to Liphofung to Tseshlanyane, and further. According to him: "The majority of the people are in favour, so it will not be a big deal." Lastly, one of the local councillors stated that she likes the idea of the park; the area is beautiful, so "it can attract tourists." For her the establishment of the park is worth having restrictions on access and use of the area "because of tourists" and "so that people can sell handicrafts to them." She continued that: "even though it is restricted, people can still use the place and when the grass is good again, it can be cut and given to the animals. In the beginning, however, one has to be strict, otherwise people don't listen. In developing things, people have to see that it works, then they will understand and appreciate it." 21

It became apparent that where some members of the 'community' believe their livelihood options will be curtailed by the park, others clearly think and hope, in line with the TFCA reasoning, that there is enough other land

\footnotetext{
${ }^{19}$ Personal Interview January 22, 2007 in Nyakonaeng, Lesotho.

${ }^{20}$ Idem.

${ }^{21}$ Personal Interview January 23, 2007, in Nyakonaeng, Lesotho.
}

on which cattle can be grazed and that a national park can attract tourists and create new livelihood opportunities.

This conflict within the wider 'community' undermines again the still popular development ideas about 'community homogeneity.' On this issue, local people were not only split between those that were informed and those that were not, but also between those believing in 'development' through the park, and those potentially threatened in their lives and livelihoods by the park. All sides were affected simultaneously by transnationalising and 'localising' dynamics, making the conflict even harder to analyze. Conflicting positions also occur within a smaller group supposedly sharing 'one' prime identity, i.e., the cattle herders. Cattle herding had always been important in Lesotho, but gained renewed significance with the return of retrenched miners, ${ }^{22}$ who now primarily have become cattle herders and need to build new livelihood strategies and identities. Yet, while for one group of herders the proposed protected area threatened their lucrative transnational cattle schemes, another group of herders in Nyakoaneng regarded the new transnational possibilities brought by the park as an opportunity. Thus, a complicated picture emerges in which local people in northeastern Lesotho seem to face many choices in terms of livelihood creation and identity building. Although these choices have of course always existed (Sen 2006), we argue that simultaneous transnationalising and localising dynamics further increased the complexity of livelihoods and 'forced' the villagers to increase their flexibility as, for example, in assuming the identity of 'protester' or 'pro-park' or choosing between traditional and democratic methods for mediation.

\section{Case 2: Proposed Golf Terrain in South Africa}

Another example of how conflict-or rather potential conflict - and transnationalism can go hand in hand and affect local life in north-eastern Lesotho is the Royal Maluti golf estate in the Free State, South Africa. Situated on a 1,472 ha site, midway between Clarens and Fouriesburg on the Caledon River, it will have two 18-hole courses and approximately 1,000 residential sites including a hospital and shopping area as well as associated infrastructure. ${ }^{23}$ Already in 2006, the local press expected the golf estate to bring a new stimulus to the stagnating Free State economy by attracting foreign tourists. ${ }^{24}$

In order to be approved by local and provincial government bodies, an Environmental Impact Assessment (EIA) was required.

\footnotetext{
${ }^{22}$ See also Boehm (2003a).

${ }^{23}$ See www.royalmaluti.com for more information.

${ }^{24}$ See http://www.bulletinonline.co.za/archives/specfeat/16july2006. php (accessed March 3, 2010).
} 
The results of the assessment were presented at a public meeting on January 19, 2007, in the municipality of Clarens as part of the public participation process. The main audience were local South African Basotho, with the two authors also attending. Clearly the most important part of the presentation, judging by the commotion in the room, was the discussion of the socioeconomic consequences of the development of the golf estate. The EIA concludes that the golf estate will bring employment to the residents of the nearby Kgubetswana (Clarens) and Mahaneeg (Fouriesburg) townships, which currently experience up to $89 \%$ unemployment (Strategic Environment Focus 2006a: 35). Plans were to establish a community trust worth Rand 35 million, run by a Community Liaison Forum for the direct benefit of the local population (e.g., offering training). What was referred to by 'local population' did not include Basotho living across the border in Lesotho. This was made clear by the presenter, who said in a raised voice, "no Lesotho residents will be employed at the expense of local residents," which earned her big applause. During the discussion that followed the presentation, it was only the South African MDTP project planner who brought up the interests of the Basotho communities living right across the international boundary, geographically much closer to the site than the two towns participating in the 'socio-environmental impact assessment' process. ${ }^{25}$ After stating that the MDTP pursued positive transnational dynamics, he suggested an agreement that would secure $5 \%-10 \%$ of the jobs for people from Lesotho. Not only do they live closest to the golf estate, he argued, but this would also honor regional cooperation plans (such as the Southern African Development Community protocol, the 'New Partnership for Africa's Development,' and others). This comment was received with indignation by the South African audience. The Royal Maluti planners, playing to the audience's sentiment, immediately promised that only South African citizens would be taken into account in the development plans - as per the legal requirement. The Royal Maluti planner stated: "Every single job will be for South African people because my responsibilities are with my shareholders and with the South African nation." Because the border is of course the legal, national boundary, the development and the public participation processes are formally restricted to South Africa.

Later research revealed that most Basotho in north-eastern Lesotho were unaware of the development of a golf course. Neither the Area Chief nor the Principal Chief of the area adjacent to the border had heard about its possible establishment. Still they were confident that the District Authorities of Clarens, with whom they convene regularly to discuss crossborder matters, will bring up the issue in one of their meetings.

\footnotetext{
${ }^{25}$ In fact, a Lesotho village lies on a hill-side overlooking the valley where the golf estate is being built (see also Fig. 2).
}

Interestingly, the constraints placed by the legal boundary did not seem to be very problematic to them. The Lesotho Chief of the bordering area reasoned that it was clear that his people would have the jobs in the end, because "the people from Clarens and Fouriesburg are not prepared to travel to this remote place. ${ }^{, 26}$ Whether this is wishful thinking or not is still to be seen, and in any event is not the main issue, which is that other (transnational) issues than excluding Lesotho inhabitants from official processes in South Africa seem to pose bigger problems.

Three major transnational issues are especially important and very likely to fuel the looming local conflict over the golf estate.

The first centres on the use of Lesotho's most valuable resource - water-by the golf estate. It was during the EIA when one of the presenters intentionally or not referred to the importance of water while trying to convince the audience of his sincerity: "If we do not perform, cut off our water." According to the planners, the golf course will be supplied with water directly from the Lesotho Highland Water Project (LHWP) scheme by accessing the underground tunnel that transports the water from the high altitude water reservoirs in Lesotho to the Ash River in South Africa. Neither the population of Lesotho nor the communities in the Free State have access to this water, as it is diverted directly to the Gauteng region of South Africa. And people are aware of this. The Muela Dam, which is a part of the infrastructure of the LHWP, is situated next to the village of Nyakoaneng. One of the villagers said that "the Highlands Water Project has helped only the people in South Africa and not the communities here. Our community does not have running water or electricity although the Muela Dam is right round the corner." ${ }^{27}$ A shared dream of many of the villagers, expressed during interviews, was for "running water." In a water-poor region like Southern Africa, it is exactly these types of situations that according to Solomon and Turton (2000) are likely to create social unrest and conflict.

The second issue is the changing nature of the border and especially its further solidification where it used to be flexible. While in international and national law it is portrayed as a strict dividing line, the north-eastern Lesotho-South Africa Free State border is geographically only a small river. Apart from the border-crossings, the few parts that are fenced are done so poorly and do not obstruct free movement. Herders from Lesotho with their cattle can frequently be spotted on the South African side of the Caledon River and South African farmers employ day labourers from Lesotho in their fields. ${ }^{28}$

\footnotetext{
${ }^{26}$ Personal Interview, March 15, 2007 in Mokhunoane, Lesotho.

${ }^{27}$ Personal Interview, January 21, 2007 in Nyakoaneng, Lesotho.

${ }^{28}$ Observation and interview data. See also Coplan $(2001,2006)$ and Steinberg (2005).
} 
The building of the golf estate, however, would lead to the establishment of a gated community along the border with a stringent security strategy including an electric fence system and regular patrols in place (Strategic Environment Focus 2006b). This complicates transnational relations on the local level in the same area where the MDTP aims to correct the arbitrariness with which African borders have been drawn historically and to reconcile communities that are divided by this border (Derwent et al. 2003). It could as well be seen as obstructing efforts by the District Authorities of Clarens to establish cordial cross-border relations with Lesotho Chiefs through regular meetings and exchange of experiences.

An added complication to the solidification of the border is that inequality will be solidified too. Royal Maluti boasts on its website that "an incomparable setting, untouched beauty as far as the eye can see and world-class facilities set Royal Maluti apart". ${ }^{29}$ Indeed, the "incomparable" and "unmatched" facilities include - besides the two golf courses - a "village square with exclusive retail and restaurant facilities," a gymnasium, tennis courts, squash courts, indoor pool facilities, a wellness centre, an equestrian centre, and "children's entertainment facilities." The houses built will be "distinctive and timeless" and will "reflect international luxury in union with nature and the location" (see Fig. 1). All this stands in stark contrast to the services, houses and living conditions of the local people, both those across the border in Lesotho (see Fig. 2) and the township dwellers of Clarens and Fouriesburg. But the problem is not just of "unrivalled luxury" and unrivalled poverty side-by-side. The securitization of the land also means fewer possibilities for land-based livelihoods for local Basotho people.

The third major issue centres on historical demographic patterns. The overwhelming majority of the African communities of Kgubetswana and Mahaneeg are in fact Basotho people who had moved to the Free State or were born in the 'Conquered Territory.' Their identification with the South African state and condemnation of the MDTP's suggestion to share benefits of the golf estate across the border (and thus their support of the white golf estate planners), explicitly meant the exclusion of their 'brothers and sisters' across the border. Their approval of the EIA report in order to keep the opportunities for jobs also meant the silent sanctioning of the above-mentioned security measures. Consequently, the Basotho of Lesotho will in the near future be regarded as "trespassers" (Strategic Environment Focus 2006a: 44) into what was once their ancestral territory whose status they still dispute and into which they extend their social spaces and livelihoods. ${ }^{30}$ While Morebane's grandmother, like many others, was working as a day labourer on the white farms

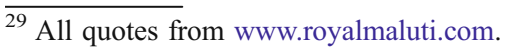

${ }^{30}$ See Coplan $(2001,2006)$, Steinberg (2005) and own interview data and observation.
}

\section{Distinctive $A_{\text {ND }}$ Timeless}

In keeping with the uniqueness and immense beauty of the property. architecture for houses and fractional title units will reflect international luxury in union with nature and the location.

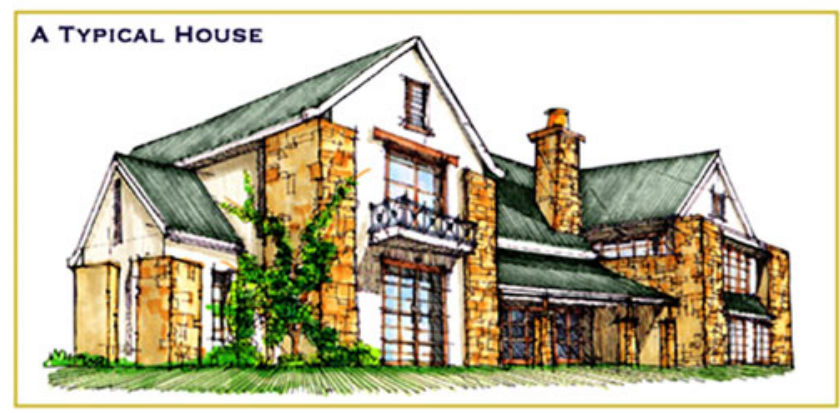

Fig. 1 'A typical house' on Royal Maluti golf estate (www. royalmaluti.com)

just across the Caledon River, he himself will be denied this opportunity with regard to the work on the golf estate. $\mathrm{He}$ also has family in the Free State and regularly goes shopping in Clarens for, e.g., seeds and-more recently-for his wedding rings.

It is interesting here that with new (transnational) influences, new alliances are forged. The Basotho do not cling to historically relevant group boundaries or identities (black vs. white, Basotho united) but forge flexible alliances built on the basis of local interest and the need to diversify livelihood strategies according to new opportunities.

\section{Conclusion: Conserving Conflict?}

The dynamics of transnationalisation and localisation as they are occurring in north-eastern Lesotho harbour a

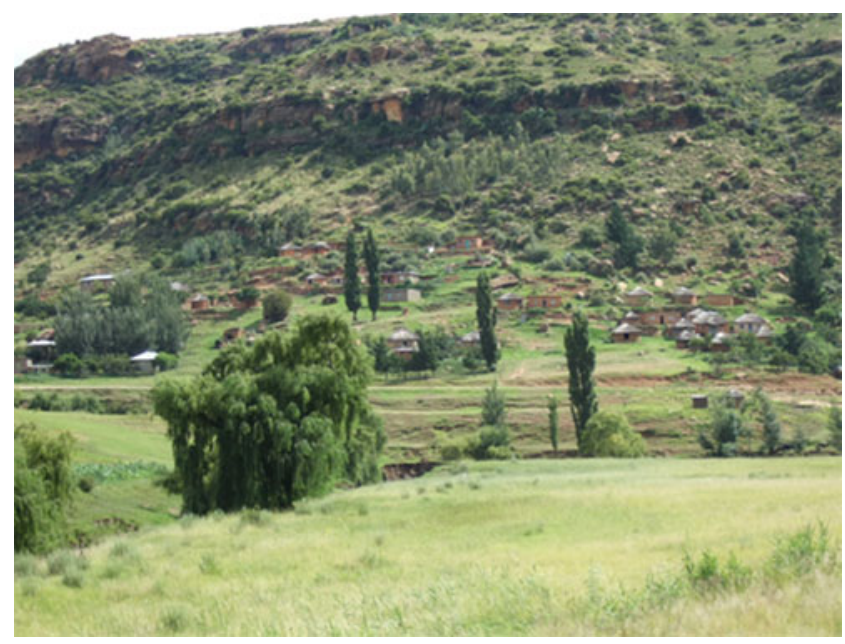

Fig. 2 The view from the future golf terrain, across the border (the river bed of the Caledon River in foreground of picture), onto a village in Lesotho (Picture taken by first author) 
diversity of elements. The examination of two local conflicts sharply brought to the fore that in interaction with these dynamics 'the locals' are forced to continuously enhance their flexibility in face of an ever-increasingly complex configuration of livelihood, identity and alliances. We have described the historical constitution of 'the Basotho' to show that the transnational context of their life worlds is not new. However, it is through their interaction with the concrete presence of two generally 'abstract' contemporary dynamics, transnationalisation by the MDTP and increased localisation through retrenchments, that consequences for livelihoods and identity seem to be sharply highlighted. It is especially within the framework of conflicts (potential conflicts) that the meaning of 'local' stretches, is redefined and reworked. 'The local' him- or herself makes new choices concerning livelihood options (e.g., ecotourism initiatives or cattle herding), identity (protester or pro-park) and alliances (South African or Basotho).

Transnational conservation and development discourses, such as within the MDTP, target and would like to engage with the political level of everyday life decisions. Yet, this is also the level at which interventions such as those of the MDTP find hardest to engage with effectively (Ferguson 1994), which in fact often leads them to stay focused on discourse rather than practice (Büscher and Dressler 2007; Büscher 2009, 2010a). This very tendency further reduces the chances for interventions to reach their 'win-win' objectives and in fact, might even have the opposite effect of 'conserving conflict.' After all, when interventions focus on their political positioning, they lose sight of the fact that in the end it is (still) the land that is the "key element of localisation" (Staring et al. 1997: 19) and is exactly what is important in the context of multiple localities. In Liqobong, it is the land used by cattle herders; between Clarens and Fouriesburg, it is the land known as 'Conquered Territory.' Viewed from an historical perspective, the transnational context in which locality is constructed in north-eastern Lesotho becomes evident.

Acknowledgements We thank Ton Salman, Marjo de Theije, Bernhard Venema and two anonymous reviewers for incisive comments on earlier drafts of this article. We also thank all those in Lesotho and South Africa who patiently answered our questions and invited us into their homes and offices.

Open Access This article is distributed under the terms of the Creative Commons Attribution Noncommercial License which permits any noncommercial use, distribution, and reproduction in any medium, provided the original author(s) and source are credited.

\section{References}

Adams, W., and Hulme, D. (2001). Conservation and community. Changing narratives, policies \& practices in African conservation. In Hulme, D., and Murphree, M. (eds.), African Wildlife and Livelihoods. The Promise and Performance of Community Conservation, James Currey, Oxford.

Anderson, D., and Grove, R. (1987). The scramble for Eden: Past, present and future in African conservation. In Anderson, D., and Grove, R. (eds.), Conservation in Africa. People, Policies and Practice, Cambridge University Press, Cambridge.

Beinart, W., and McGregor, J. (2003). Social History and African Environments, James Currey, Oxford.

Boehm, C. (2003a). The Social Life of Fields: Labour Markets and Agrarian Change in Lesotho. Paideusis - Journal for Interdisciplinary and Cross-Cultural Studies 3: 1-20.

Boehm, C. (2003b). Our fields are weak nowadays-Unemployment, Social Reproduction and Agrarian Change in Lesotho, Southern Africa. Paper presented at the conference 'Local Land Use Strategies in a Globalizing World: Shaping Sustainable Social and Natural Environments', Institute of Geography Geocenter, University of Copenhagen, Denmark, August 21-23.

Brockington, D. (2002). Fortress Conservation. The Preservation of the Mkomazi Game Reserve, Tanzania, James Currey, Oxford.

Brockington, D., Duffy, R., and Igoe, J. (2008). Nature Unbound. Conservation, Capitalism and the Future of Protected Areas, Earthscan, London.

Brosius, J. P., Tsing, A. L., and Zerner, C. (eds.) (2005). Communities and Conservation. Histories and Politics of Community-Based Natural Resource Management, AltaMira, Lanham.

Büscher, B. (2009). Struggles over Consensus, Anti-Politics and Marketing. Neoliberalism and Transfrontier Conservation and Development in Southern Africa. PhD. dissertation, Vrije Universiteit Amsterdam.

Büscher, B. (2010a). Anti-Politics as Political Strategy: Neoliberalism and Transfrontier Conservation in Southern Africa. Development and Change 41(1): 29-51.

Büscher, B. (2010b). Seeking Telos in the 'Transfrontier': Neoliberalism and the Transcending of Community Conservation in Southern Africa. Environment and Planning A 42(3): 644-660.

Büscher, B., and Dressler, W. (2007). Linking Neoprotectionism and Environmental Governance: on the Rapidly Increasing Tensions Between Actors in the Environment-Development Nexus. Conservation and Society 5: 586-611.

Coplan, D. B. (2001). A River Runs Through it: The Meaning of the Lesotho-Free State Border. African Affairs 100: 81-116.

Coplan, D. B. (2006). Border Burlesque: Deception and Disappearance on the New South African-Lesotho Frontier. Paper presented the Forced Migration Studies Programme, February 28, 2006, University of Witswatersrand, South Africa.

Davids, T., and van Driel, F. (2005). Changing perspectives. In Davids, T., and van Driel, F. (eds.), The Gender Question in Globalization, Ashgate, Aldershot.

Derwent, S., Porter, R., and Sandwith, T. (eds.). (2003). MalotiDrakensberg Transfrontier Conservation and Development Programme. Ezemvelo KwaZulu-Natal Wildlife.

Draper, M., Spierenburg, M., and Wels, H. (2004). African Dreams of Cohesion: Elite Pacting and Community Development in Transfrontier Conservation Areas in Southern Africa. Culture and Organization 10(4): 341-353.

Dressler, W. (2009). Old Thoughts in New Ideas. State Conservation Measures, Development and Livelihood on Palawan Island, Ateneo de Manila University Press, Manila.

Dressler, W., and Büscher, B. (2008). Market Triumphalism and the so-called CBNRM 'crisis' at the South African Section of the Great Limpopo Transfrontier Park. Geoforum 39(1): 452465.

Dressler, W., Büscher, B., Schoon, M., Brockington, D., Hayes, T., Kull, C., McCarthy, J., and Streshta, K. (2010). From Hope to Crisis and Back? A Critical History of the Global CBNRM Narrative. Environmental Conservation 37(1): 5-15. 
Duffy, R. (2006). The Potential and Pitfalls of Global Environmental Governance: The Politics of Transfrontier Conservation Areas in Southern Africa. Political Geography 25: 89-112.

Fabricius, C. (2004). The fundamentals of community-based natural resource management. In Fabricius, C., Koch, E., Magome, H., and Turner, S. (eds.), Rights Resources \& Rural Development. Community-Based Natural Resource Management in Southern Africa, Earthscan, London.

Ferguson, J. (1994). The Anti-Politics Machine. "Development," Depoliticization, and Bureaucratic Power in Lesotho, University of Minnesota Press, Minneapolis.

Ferguson, J. (2006). Global Shadows. Africa in the Neoliberal World Order, Duke University Press, Durham.

Ghimire, K. B., and Pimbert, M. P. (1997). Social change and conservation: an overview of issues and concepts. In Ghimire, $\mathrm{K}$. B., and Pimbert, M. P. (eds.), Social Change and Conservation: Environmental Politics and Impacts of National Parks and Protected Areas, Earthscan, London.

Holt, F. L. (2005). The Catch-22 of Conservation: Indigenous Peoples, Biologists, and Cultural Change. Human Ecology 33(2): 199215.

Hughes, D. M. (2002). When Tourists Cross Boundaries and Peasants Don't: Inequality and Regional Metaphors in the Great Limpopo Conservation Area. Paper presented in the proceedings of a workshop, Department of Economic History, University of Zimbabwe, Harare, September 13.

Hughes, D. M. (2005). Third Nature: Making Space and Time in the Great Limpopo Conservation Area. Cultural Anthropology 20(2): $157-184$.

Hughes, D. M. (2006). From Enslavement to Environmentalism. Politics on a Southern African Frontier, University of Washington Press, Seattle.

Igoe, J., and Fortwangler, C. (2007). Whither Communities and Conservation? International Journal of Biodiversity Science \& Management 3: 65-76.

Maloti-Drakensberg Transfrontier Project (2006) MDTP News Quarterly 2 (1). Howick, Maseru: MDTP.

Marcus, R. R. (2001). Seeing the Forest for the Trees: Integrated Conservation and Development Projects and Local Perceptions of Conservation in Madagascar. Human Ecology 29(4): 381397.

Murray, C. (1981). Families Divided. The Impact of Migrant Labour in Lesotho, Cambridge University Press, Cambridge.
Neumann, R. P. (1998). Imposing Wilderness, Struggles Over Livelihood and Nature Preservation in Africa, University of California Press, Berkely.

Orlove, B. S., and Brush, S. B. (1996). Anthropology and the Conservation of Biodiversity. Annual Review of Anthropology 25: 329-352.

Ribot, J. C., and Peluso, N. L. (2003). A Theory of Access. Rural Sociology 68(2): 153-181.

Sen, A. (2006). Identity and Violence: The Illusion of Destiny, W.W. Norton \& Company, New York.

Solomon, H., and Turton, A. (eds.) (2000). Water Wars: Enduring Myth or Impending Reality, ACCORD, Durban.

Spierenburg, M., and Wels, H. (2006). "Securing Space": Mapping and Fencing in Transfrontier Conservation in Southern Africa. Space and Culture 9(3): 294-312.

Staring, R., van der Land, M., Tak, H., and Kalb, D. (1997). Localizing Cultural Identity. Focaal 30(31): 7-21.

Steinberg, J. (2005). The Lesotho/Free State Border. ISS Paper 113, Institute for Security Studies, Pretoria, Capetown.

Strategic Environment Focus (2006a). Environmental Scoping Report for the proposed Royal Maluti Golf and Eco Estate, SEF, Lynwood Ridge.

Strategic Environment Focus (2006b). Social Impact Assessment (SEF REF: 500462), SEF, Lynnwood Ridge.

Thompson, L. (2006). A History of South Africa, Jonathan Ball, Jeppestown.

Turner, S. D. (2005a). The Underlying Causes of Poverty in Lesotho, CARE Lesotho, Maseru.

Turner, S. D. (2005b). Livelihoods and Sharing: Trends in a Lesotho Village 1976-2004, Research report no. 22. University of the Western Cape, Programme for Land and Agrarian Studies/Care.

West, P. (2006). Conservation is Our Government Now. The Politics of Ecology in Papua New Guinea, Duke University Press, Durham.

West, P., and Brockington, D. (2006). Some Unexpected Consequences of Protected Areas: An Anthropological Perspective. Conservation Biology 20(3): 609-616.

Wittmayer, J. M. (2007). Life Projects, Development and the State. An anthropological study into land claims in Lesotho. MSc Thesis, Vrije Universiteit, Amsterdam.

Wolmer, W. (2003). Transboundary Conservation: the Politics of Ecological Integrity in the Great Limpopo Transfrontier Park. Journal of Southern African Studies 29(1): 261-278. 